\title{
Natural Bioactive Compounds of Sechium spp. for Therapeutic and Nutraceutical Supplements
}

\section{OPEN ACCESS}

Edited by:

Alessandra Durazzo,

Research Centre for Food and Nutrition, Council for Agricultural Research and Economics, Italy

Reviewed by:

Umakanta Sarker, Bangabandhu Sheikh Mujibur Rahman Agricultural University,

Bangladesh

Arpita Roy,

Sharda University, India

Rosalinda Gonzalez,

Universidad Autónoma de Querétaro

Mexico

*Correspondence

Jorge Cadena-Iñiguez

jocadena@gmail.com

Ramón Marcos Soto-Hernández

msoto@colpos.mx

tThese authors have contributed equally to this work and share first authorship

${ }^{\ddagger}$ Deceased

Specialty section:

This article was submitted to

Plant Metabolism

and Chemodiversity,

a section of the journa

Frontiers in Plant Science

Received: 08 September 2021

Accepted: 11 November 2021

Published: 21 December 2021

Citation:

Iñiguez-Luna MI,

Cadena-Iñiguez J,

Soto-Hernández RM, Morales-Flores FJ, Cortes-Cruz M and Watanabe KN (2021) Natural Bioactive Compounds of Sechium spp. for Therapeutic and Nutraceutical Supplements.

Front. Plant Sci. 12:772389.

doi: $10.3389 / \mathrm{fp} / \mathrm{s} .2021 .772389$
María Isabel Iñiguez-Luna ${ }^{1,2 \dagger}$, Jorge Cadena-Iñiguez ${ }^{1,2 *}$, Ramón Marcos Soto-Hernández ${ }^{2,3 * t}$, Francisco Javier Morales-Flores ${ }^{1,2}$, Moisés Cortes-Cruz ${ }^{2,4 \neq}$ and Kazuo N. Watanabe ${ }^{2,5}$

${ }^{1}$ Postgrado de Innovación en Manejo de Recursos Naturales, Colegio de Postgraduados, San Luis Potosí, Mexico, ${ }^{2}$ Interdisciplinary Research Group at Sechium edule in Mexico, A.C., Texcoco, Estado de México, Mexico, ${ }^{3}$ Programa de Botánica, Colegio de Postgraduados, Montecillo, Mexico, ${ }^{4}$ Centro Nacional de Recursos Genéticos-INIFAP, Tepatitlán, Mexico, ${ }^{5}$ Tsukuba Plant Innovation Research Center, University of Tsukuba, Tsukuba, Japan

Natural products are in great demand because certain secondary metabolites (SMs) are sources of antioxidants, flavorings, active substances, or anticancer agents with less aggressiveness and selectivity, among which triterpenes and flavonoids are of importance because they inhibit carcinogenesis. For Sechium spp. P. Br. (chayotes), there is scientific evidence of antiproliferative activity that has occurred when cancer cell lines have been treated with this fruit. In order to compare future therapeutic designs and identify new and ancestral characteristics, triterpenes and flavonoids were determined in contrasting Sechium genotypes. The obtained data were analyzed via a cladistics approach, with the aim of identifying the characteristics and state of phytochemicals and genetic variables. The concentrations of flavonoids and triterpenes were determined, and a more complex composition of secondary metabolites was found in the wild types as compared to their domesticated genotypes. Bitter fruits contained a higher number of SMs, followed by those with a neutral and sweet flavor. A cladogram showed the differentiation of the three groups based on the flavor of the fruits. The diversity of SMs decreases in evolutionary terms, in response to domestication and environmental adaptation. Therefore, genotypes can be feasibly selected based on fruit flavor for gross-breeding, and cytotoxicity can be reduced without losing possible therapeutic effects.

Keywords: cucurbitacins, flavonoids, fruit, cancer, diabetes, endemic species

\section{INTRODUCTION}

The use of medicinal plants is based on empirical knowledge that has been preserved for generations, with the aim of improved or recovered health (Palma-Tenango et al., 2017). In Mexico, it is estimated that there are 5,000 species of plants with healing properties (Villaseñor, 2016); similarly, different active substances have been isolated from these, sometimes obtaining more

Abbreviations: AFLP, amplified fragment length polymorphism; BANGESe, National Germplasm Bank of Sechium edule; CuD, cucurbitacin D; CuI, cucurbitacin I; CuB, cucurbitacin B; CuE, cucurbitacin E; Ru, rutin; Fz, florizidin; Mi, myricetin; $\mathrm{Qu}$, quercetin; Na, naringenin; Ft, floretin; Ap, apigenin; Ga, galangin; P388, leukemia in mice; L929, mouse fibroblast cell line; J774, mouse macrophage cell line; HeLa, Henrietta Lacks, human cervical cancer cell line; WEHI-3, leukemic cells. 
than one per plant (Molina-Mendoza et al., 2012). These substances correspond to secondary metabolites (SMs), which are biomolecules that enable plants to survive, adapt, and reproduce when they are threatened by predators or stress conditions (Piasecka et al., 2015).

Recently, SMs have become increasingly important in the food, industrial, cosmetic, textile, and pharmaceutical sectors (Bourgaud et al., 2001), and approximately 200,000 SMs have been identified (Croteau et al., 2000). Some species of the genus Sechium P. Browne (Cucurbitaceae) are found among plants with broad diversity and complex composition as reported in Mexico, whose fruits are known as chayotes (Lira et al., 1999; Cadena-Iñiguez et al., 2011). The SMs confer particular characteristics to this species, thereby creating morpho-biochemical differences that affect the phenotype, and there is evidence in Sechium of morpho-biochemical changes in edible types. Among the phyto compounds that have aroused particular interest are triterpenes, due to their antiproliferative properties. These have been evaluated with different in vitro and in vivo models, in an attempt to define their mechanism of action and effects when they are used as cancer cell treatments (Vega et al., 2006; Petronelli et al., 2009; Bishayeen et al., 2011; Aguiñiga-Sánchez et al., 2017). Flavonoids are metabolites identified in Sechium, and there are reports of their antineoplastic activities (Deschner et al., 1993; Manach et al., 1996; Salazar-Aguilar et al., 2017).

In the development of anticancer compounds from natural sources, various active substances have been extracted and commercialized, such as vincristine, camptothecin, and taxol. However, some of these have shown toxic effects or non-selective activities, resulting in the elimination of every cell with a high proliferation rate, such as lymphocytes and hair cells (Vega et al., 2006; Jacobo-Herrera et al., 2016). Under this premise, genetic improvement has begun with certain types of chayote because antineoplastic activity has been demonstrated through bioassays in the WEHI-3, HeLa, P388, J774, and L929 cell lines, among other principal ones (Cadena-Iñiguez et al., 2013; AguiñigaSánchez et al., 2015, 2017; Salazar-Aguilar et al., 2017). In bone marrow mononuclear cells, DNA fragmentation of malignant cells was found, revealing the selective activity of chayote extracts. The advantages cited, in addition to being a genus that integrates cultivable genotypes having production yields exceeding $64 \mathrm{t} \mathrm{ha}^{-1}$ per year (SIAP, 2019), confer importance to chayote as a source of biomass for active substances with pharmacological objectives.

Agrobiodiversity includes wild relatives of domesticated genotypes or in the process of domestication (Convenio de Diversidad Biológica [CDB], 2016), however, there is a risk of genetic loss or erosion due to changes in consumer preference, displacement by new cultivars and habitat fragmentation. The intra- and interspecific complexes of agrobiodiversity contain biological variants with great potential for the extraction of SMs for diverse uses and are economically important for the pharmaceutical, health and food industries (Roskov et al., 2015). It is estimated that the diversity of vascular plants in Mexico ranges from 22,000 to 31,000 species, of which about 4,000 have medicinal use (Leon-Lobos et al., 2012).
Based on the differences in the phytochemical profiles of Sechium sp., an attempt has been made to help explain the causes of the morphobiochemical changes observed in the morphotypes. However, there is interest in developing genotypes with medium-term yields in the field (biomass) to recover SMs of therapeutic interest that increases the pharmacological options and dietary supplements. Starting from the hypothesis that domesticated genotypes have lost many SMs, while wild types can be highly toxic, an evaluation of contrasting and underutilized genotypes of Sechium sp. was carried out, in order to identify SMs for pharmacological and nutraceutical use, in order that it contributes to the design of new varieties by genetic crossing to obtain bioactive natural products, and to favor their revaluation and importance as components of agrobiodiversity that reduce the risk of loss.

\section{MATERIALS AND METHODS}

\section{Materials}

Sechium spp. fruits of genotypes with contrasting flavors were chosen that were considered representative of the contrasts (Cadena-Iñiguez et al., 2011; Table 1; Figure 1). The fruits evaluated were harvested at a stage of horticultural maturity (Table 1), and all of them came from the national gene bank of Sechium edule in Mexico (BANGESe) (19 $08^{\prime} 48^{\prime \prime} \mathrm{N}, 97^{\circ} 57^{\prime} 00^{\prime \prime}$ $\mathrm{W})$. All accessions registered their entry into the germplasm bank in 2005 and have been maintained under agroclimatic conditions and equal management.

\section{Extraction Process}

The fruits were washed, cut, weighed, and then placed in a drying oven (BLUE-M, Electronic Company/Blue Island, IL, United States) with an air flow at $45^{\circ} \mathrm{C}$. After drying for $72 \mathrm{~h}$, all parts of the fruits (exocarp, mesocarp, spines, and seed) were ground in a mill (Hamilton Beach, United States). A continuous extraction of the dry ground material was carried out with methanol (Cadena-Iñiguez et al., 2013; Aguiñiga-Sánchez et al., 2017). From the ground material, $2.5 \mathrm{~g}$ were weighed for each accession and submerged in $80 \%$ methanol at a 1:10 ratio in $50 \mathrm{~mL}$ Falcon tubes. The samples were homogenized, placed in an ultrasonic bath (Branson B-220 50/60 Hz) at room temperature,

TABLE 1 | Main characteristics of the accessions of Sechium spp. based on fruit color and flavor $(n=27)$.

\begin{tabular}{lccrc}
\hline Genotype & Accession & Color & Flavor & Status \\
\hline S. edule var. albus levis & 769 & yellow & sweet & Semi-domesticated \\
S. edule var. albus levis & 761 & yellow & sweet & Semi-domesticated \\
S. edule var. albus minor & 330 & yellow & sweet & Semi-domesticated \\
S. edule var. nigrum minor & 681 & dark green & neutral & Semi-domesticated \\
S. edule var. virens levis & 273 & light green & neutral & Domesticated \\
S. edule var. nigrum & $530-a$ & dark green & neutral & Domesticated
\end{tabular}

xalapensis

Sechium edule

Sechium compositum

653 dark green bitter

Wild type

Sechium compositum

Wild type

751 dark green bitter Wild type 

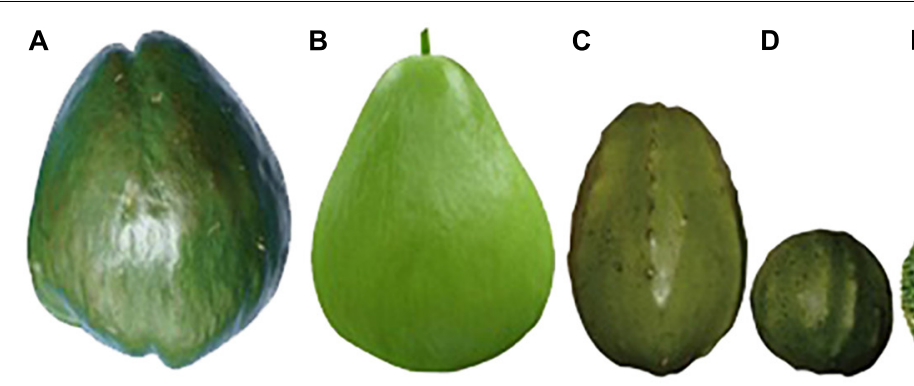

E

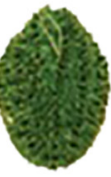

$\mathbf{F}$

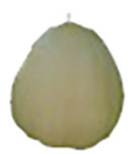

G

H

FIGURE 1 | Morphotypes of Sechium spp. evaluated. (A) S. edule var. nigrum xalapensis, (B) S. edule var. virens levis, (C) S. compositum (accession 11), (D) S. compositum (accession 751), (E) S. edule wild-type, (F) S. edule var. albus levis, (G) S. edule var. albus minor, (H) S. edule var. nigrum minor. The reference metric scale is $1 \mathrm{~cm}$ per square.

and were then subjected to two cycles of 10 min sonication and $5 \mathrm{~min}$ of rest between each cycle. Subsequently, the tubes were centrifuged at $3000 \mathrm{~g}$ for $5 \mathrm{~min}$. and the supernatant was collected in $2 \mathrm{~mL}$ amber vials, and stored in the fridge before analysis by HPLC (Aguiñiga-Sánchez et al., 2017).

\section{Determination of Cucurbitacins and Flavonoids}

Based on a previously described methodology (Salazar-Aguilar et al., 2017), cucurbitacins and flavonoids were analyzed by highperformance liquid chromatography (HPLC), where $20 \mathrm{mg}$ of extract was weighed per sample, dissolved with $1 \mathrm{~mL}$ of HPLCgrade methanol (Sigma-Aldrich, St. Louis, MO, United States), and then filtered using a nylon membrane acrodisc with a diameter of $0.45 \mu \mathrm{m}$ (Merck, Millipore, Germany).

Cucurbitacins were analyzed through a symmetry shield C18 column $(4.6 \times 250 \mathrm{~mm})$ (Waters, Spain) via an isocratic analysis. The mobile phase used was in isocratic mode with water, methanol, and acetonitrile (50:30:20 v/v), and the injection flow

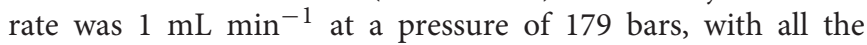
samples being at a temperature of $25^{\circ} \mathrm{C}$. The total volume injected per accession evaluated was $20 \mu \mathrm{L}$. Finally, the identification of cucurbitacins was performed using two wavelengths $(\lambda 1235 \mathrm{~nm}$ and $\lambda 2254 \mathrm{~nm}$ ). As a reference standard, cucurbitacins D, I, B, and $\mathrm{E}$ were used (Sigma-Aldrich, United States).

In the case of flavonoids, a hypersil ODS column $(125 \times 40 \mathrm{~mm})$ was used (Hewlett-Packard, United States). with a gradient of $(\mathrm{A}) \mathrm{H}_{2} \mathrm{O}$ adjusted at $\mathrm{pH} 2.5$ with trifluoroacetic acid, and (B) acetonitrile $0-10 \mathrm{~min}$, in the following mixtures A:B 85:15 for $20 \mathrm{~min}$, and A:B 65:35 for $25 \mathrm{~min}$. The following parameters were used: flow at $1 \mathrm{~mL} / \mathrm{min}$ at $30^{\circ} \mathrm{C}$, detection wavelengths, 254, 316, and $365 \mathrm{~nm}$; injection volume, $20 \mu \mathrm{L}$ and analysis time, $25 \mathrm{~min}$. The standards used were rutin, florizidin, myricetin, quercetin, naringenin, florentin, and galangin (Sigma-Aldrich, United States).

\section{DNA Extraction for Amplified Fragment Length Polymorphism Bands}

In order to demonstrate an approach to the relationship between secondary metabolites and genetic expression, DNA was extracted from the young leaves of previously evaluated accessions (Shagai-maroof et al., 1984) and characterized by AFLPs (Vos et al., 1995). A double digestion was applied to $500 \mathrm{ng}$ of DNA with EcoRI/MseI restriction enzymes (10 and $2.5 \mathrm{U} / \mu \mathrm{g}$, respectively) at $37^{\circ} \mathrm{C}$ for $4 \mathrm{~h}$. After evaluating the restriction fragments by electrophoresis in $0.8 \%$ agarose for $70 \mathrm{~min}$ at $80 \mathrm{~V}$, the ligation began by adding $10 \mu \mathrm{L}$ of a mixture of adaptors at $5 \mathrm{mg} \mathrm{kg}^{-1}$ to the T4 DNA ligase enzyme at a final concentration of $1 \mathrm{U}$.

For the pre-amplification, $4 \mu \mathrm{L}$ of the ligation product was combined with $21 \mu \mathrm{L}$ of a mixture containing starters Mse I $+\mathrm{C}$ $(5 \mu \mathrm{M})$, EcoRI + A $(5 \mu \mathrm{M})$, and $10.5 \mu \mathrm{L}$ of Sigma REDTaq ${ }^{\circledR}$ ReadyMix $^{\text {TM }}$ PCR Reaction Mix and was finally adjusted to a volume of $25 \mu \mathrm{L}$ with Type I water. The thermocycler was programmed at $94^{\circ} \mathrm{C}$ for $30 \mathrm{~s}, 56^{\circ} \mathrm{C}$ for $60 \mathrm{~s}$, and $72^{\circ} \mathrm{C}$, for 25 cycles. The result of this PCR was corroborated in $0.8 \%$ agarose gel for $60 \mathrm{~min}$ at $80 \mathrm{~V}$, and then, the pre-amplification reaction was diluted with $80 \mu \mathrm{L}$ of Type I water.

For the selective amplification, $3.0 \mu \mathrm{L}$ of the aforementioned dilution were taken, adding $3 \mu \mathrm{M}$ EcoRI + ACC marked with FAM and $5 \mu \mathrm{M} \mathrm{MseI}+\mathrm{CAT}$, and adjusting to a final volume of $10 \mu \mathrm{L}$ with $1 \times$ SIGMA REDTaq $^{\circledR}$ ReadyMix $^{\text {TM }}$ PCR Reaction Mix. The thermocycler was programmed at $95^{\circ} \mathrm{C}$ for $5 \mathrm{~min}$, followed by 35 cycles $\left(95^{\circ} \mathrm{C}\right.$ for $40 \mathrm{~s}, 54^{\circ} \mathrm{C}$ for $40 \mathrm{~s}$, and $72^{\circ} \mathrm{C}$ for $90 \mathrm{~s}$ ) and final elongation at $72^{\circ} \mathrm{C}$ for $40 \mathrm{~min}$.

The product of the amplification was observed in a $6 \%$ polyacrylamide gel that underwent electrophoresis at $200 \mathrm{~V}$ for $3 \mathrm{~h}$. The gels were dyed with silver nitrate as soon as the fragments were visualized, and then, a dilution (1:10) of the PCR-selective and formamide products (Hi-Di ${ }^{\mathrm{TM}}$ Formamide, United States) was prepared and evaluated in a capillary sequencer 3500 XL Genetic Analyzer (ThermoFisher Scientific, United States) along with the fragment analysis running model (FragmentAnalysis50_POP7xl_2, Fragment_Analysis_PA_Protocol). Using the amplification data (size of the fragment), a binary matrix of presence and absence $(1 / 0)$ was generated through the Gene Mapper 4.1 software (GeneMapper, Applied Biosystems).

\section{Statistical Analysis}

The data were analyzed via a cladistics approach with WinClada 1.00.08 (2002) (WinClada v.1.00.08, 2020). The applied analysis 
was heuristic, with the Bootstrap/Jackknife tests, which generated the index of consistency and stability, respectively (Felsenstein, 1985; Lanyon, 1985).

\section{RESULTS}

\section{Phytochemical Screening}

The relationship between fresh and dry weight and extract yield showed that on average, the genotypes evaluated were composed of $73.85 \%$ water. As previously noted, fruits with a yellow epidermis (albus minor, albus levis) showed a lower percentage (52.27\%), and those with the highest water content were the green fruits with a neutral flavor $(82.40 \%)$, followed by the wild types accounting for $79.76 \%$. In the case of the extract yield, $52.98 \%$ was found for genotypes of neutral flavor, while the albus (yellow) yielded 39.26\%, and finally the wild fruits of bitter flavor accounted for $37.27 \%$ (Table 2 ).

High-performance liquid chromatography analysis revealed the presence of cucurbitacins I, D, B, and E, and in terms of flavonoids, rutin, myricetin, and floretin were found in all the genotypes, while galangin was present in all except for virens levis and nigrum xalapensis (neutral flavor). Quercetin was found in six of the nine genotypes, and was absent in albus levis, virens levis, and nigrum xalapensis. Naringenin was observed in albus minor and the two wild ones of $S$. compositum. Finally, florizidin was identified in virens levis and in accession 11 of S. compositum (Tables 3, 4).

The genotypes with higher concentrations of cucurbitacin D $(\mathrm{CuD})$ and $\mathrm{CuE}$ were yellow fruits (albus minor, albus levis), while higher amounts of $\mathrm{CuB}$ and $\mathrm{CuI}$ were found in bitter chayotes (S. compositum and $S$. edule). In the case of $\mathrm{CuD}$, the highest concentration was found in nigrum xalapensis, followed by albus minor and S. compositum. In terms of CuI, the highest value was identified in $S$. compositum and nigrum minor, and in the case of $\mathrm{CuB}$, the highest concentration was for S. compositum and albus minor. The only material that contained $\mathrm{CuE}$ was albus levis (accession 761).

High-performance liquid chromatography analysis for flavonoids showed that there were seven to eight standards in the evaluated genotypes, and no apigenin was reported. Rutin, myricetin, quercetin, and galangin were identified from the groups of flavonols, florizidin and floretin were identified from the chemical group of dihydrochalcones, and only naringenin
TABLE 3 | Yield of cucurbitacins obtained from fruits at horticultural maturity stage of contrasting flavor of Sechium spp. $(n=27)$.

\begin{tabular}{lcccc}
\hline Genotype & \multicolumn{4}{c}{$\mathbf{m g ~ g}^{-1}$} \\
\cline { 2 - 5 } & CuD & Cul & CuB & CuE \\
\hline S. edule var. albus levis & 1.17 & 4.27 & 1.27 & 0 \\
S. edule var. albus levis & 4.77 & 3.52 & 0.46 & 1.73 \\
S. edule var. albus minor & 12.71 & 1.93 & 1.52 & 0 \\
S. edule var. nigrum minor & 1.06 & 5.84 & 0.27 & 0 \\
S. edule var. virens levis & 0.95 & 4.04 & 0.62 & 0 \\
S. edule var. nigrum xalapensis & 13.44 & 5.60 & 0.73 & 0 \\
Sechium compositum & 3.00 & 4.70 & 1.96 & 0 \\
Sechium compositum & 8.35 & 17.47 & 4.37 & 0 \\
Sechium edule wild type & 1.04 & 3.10 & 0.18 & 0 \\
\hline
\end{tabular}

$C U D=$ cucurbitacin $D ;$ Cul = cucurbitacin $1 ; \operatorname{CuB}=$ cucurbitacin $B ;$ $C U E=$ cucurbitacin $E$.

TABLE 4 | Flavonoid content obtained from fruits at horticultural maturity stage of contrasting flavor of Sechium spp. $(n=27)$.

\begin{tabular}{|c|c|c|c|c|c|c|c|c|}
\hline \multirow[t]{2}{*}{ Genotype } & \multicolumn{7}{|c|}{$\mathrm{mg} \mathrm{g}^{-1}$} & \multirow[b]{2}{*}{$\mathrm{Ga}$} \\
\hline & $\mathbf{R u}$ & $\mathbf{F z}$ & My & Qu & $\mathrm{Na}$ & $\mathbf{F t}$ & Ap & \\
\hline S. edule var. albus levis & 0.26 & 0.00 & 0.78 & 0.00 & 0.00 & 0.09 & 0 & 0.46 \\
\hline S. edule var. albus levis & 0.13 & 0.00 & 0.55 & 0.00 & 0.00 & 0.10 & 0 & 0.43 \\
\hline $\begin{array}{l}\text { S. edule var. albus } \\
\text { minor }\end{array}$ & 0.25 & 0.00 & 0.69 & 0.01 & 0.16 & 0.05 & 0 & 0.48 \\
\hline $\begin{array}{l}\text { S. edule var. nigrum } \\
\text { minor }\end{array}$ & 0.13 & 0.00 & 0.27 & 0.01 & 0.00 & 0.06 & 0 & 0.44 \\
\hline S. edule var. virens levis & 0.23 & 0.08 & 1.09 & 0.00 & 0.00 & 0.11 & 0 & 0.00 \\
\hline $\begin{array}{l}\text { S. edule var. nigrum } \\
\text { xalapensis }\end{array}$ & 0.08 & 0.00 & 0.77 & 0.00 & 0.00 & 0.15 & 0 & 0.00 \\
\hline Sechium compositum & 0.48 & 0.11 & 0.19 & 0.03 & 0.56 & 1.42 & 0 & 5.80 \\
\hline Sechium compositum & 1.20 & 0.00 & 1.46 & 0.21 & 1.59 & 2.19 & 0 & 12.32 \\
\hline $\begin{array}{l}\text { Sechium edule wild } \\
\text { type }\end{array}$ & 0.82 & 0.00 & 1.10 & 0.09 & 0.00 & 0.06 & 0 & 0.51 \\
\hline
\end{tabular}

$R u=$ rutin; $F z=$ florizidin; $M y=$ myricetin; $Q u=$ quercetin; $N a$ = naringenin; $\mathrm{Ft}=$ floretin; $\mathrm{Ap}=$ apigenin; $\mathrm{Ga}=$ galangin .

came from flavones. In general, the highest concentration of flavonoids was quantified in bitter genotypes, followed by chayotes of neutral flavor. Only rutin and naringenin flavonoids were found in higher quantities in yellow fruits (albus levis and albus minor) (Table 4).

TABLE 2 | Relationship between fresh, dry weight, and percentage yield of extracts from fruits at horticultural maturity stage of Sechium spp. ( $n=27$ ).

\begin{tabular}{|c|c|c|c|c|c|c|c|c|c|}
\hline \multicolumn{10}{|c|}{ Fruit flavor/accession } \\
\hline \multirow[t]{2}{*}{ Variable } & \multicolumn{3}{|c|}{ Sweet } & \multicolumn{3}{|c|}{ Neutral } & \multicolumn{3}{|c|}{ Bitter } \\
\hline & 769 & 761 & 330 & 681 & 273 & $530-a$ & 11 & 751 & 653 \\
\hline Fresh weight (g) & 84.94 & 34.3 & 10.44 & 9.63 & 360 & 390 & 555 & 147.24 & 119.41 \\
\hline Dry weight (g) & 27.6 & 19.1 & 4.7 & 3.3 & 37.9 & 29.7 & 80.6 & 27.3 & 33.00 \\
\hline Water (\%) & 67.5 & 55.68 & 54.98 & 65.33 & 89.5 & 92.38 & 85.47 & 81.45 & 72.36 \\
\hline Dry matter (\%) & 32.49 & 44.31 & 45.02 & 34.26 & 10.5 & 7.61 & 14.52 & 18.54 & 27.63 \\
\hline Extract $(\mathrm{g})$ & 1.15 & 1.08 & 0.71 & 1.07 & 1.29 & 1.61 & 0.94 & 1.01 & 0.85 \\
\hline Total yield (\%) & 46.04 & 43.29 & 28.47 & 42.94 & 51.6 & 64.37 & 37.44 & 40.52 & 33.91 \\
\hline
\end{tabular}




\section{Combination of Phytochemical Variables and Polymorphic Bands of Amplified Fragment Length Polymorphisms}

Figure 1 shows the parsimonious arrangement of the combination of phytochemical variables and polymorphic bands of AFLPs (one thousand repetitions), signaling a reconstruction of inheritable similarities, where bitter chayotes of dark green color with spines were the genotypes most proximal to the root of the monophyletic tree, corresponding to ancestral characteristics. The cladogram shows the three groups distinguished by the flavor of the fruits. The first was formed by bitter genotypes, placing S. edule as the root taxon, followed by the two accessions of S. compositum. Similarly, the second group was formed by green chayotes of neutral flavor, and the last group was formed by those of yellow fruit of sweet flavor. Accordingly, and under a cladistics view, an evolutionary arrangement was marked, suggesting that the bitter flavor is an ancestral characteristic that changes (decreases) due to differences in secondary metabolites and associated polymorphic bands. The first case was observed in the group of bitter chayotes, where an absence of the 16 (77 pb) band was found in the ancestral traits (dark circles) of $S$. edule and S. compositum (accession 11), as well as the mean concentration of $\mathrm{CuD}$ in accession 751 of $S$. compositum.

It is difficult to consider abrupt changes in the genotypes of a species in the same agroclimatic region of distribution. However, small differences attributed to the same environment can possibly be identified. For example, even when accession 11 and 751 are $S$. compositum and come from the same region (Chiapas, Mexico), the first one comes from the evergreen tall forest, and the second comes from ruderal conditions without vegetation, which can timely mark modifications in the phenotype. Plasticity is a trait that allows plants to carry out morphological and biochemical adjustments, and especially for this case, accession 11 is of pyriform fruit, while accession 751 is round and small (Figure 1). The second group included genotypes with neutral-flavor fruits and corresponded to those with the highest consumption and commercial manipulation, indicating the presence of cucurbitacin B, rutin, and myricetin, which are classified as apomorphic traits (new). Finally, the genotypes albus minor, albus levis, and even nigrum minor, considered as semi-domesticated, of low consumption, and conserved in family backyards, exhibited six traits (Table 5), half of which corresponded to phytochemicals with mean values in terms of concentration of cucurbitacins $\mathrm{D}$ and $\mathrm{E}$, such as the symplesiomorphic trait (ancestral and shared with the other genotypes), and the presence of band 54 (426 pb), as an autapomorphic trait (new).

With regard to polymorphic bands associated with phytochemical traits (Figure $\mathbf{2}$ and Table 5), it is assumed that they are non-coding DNA, neutral to selection. This is why, it is necessary to understand what type of information these bands contain and why they need to be isolated, cloned, and sequenced, and then make an alignment ("blast") to identify possible associations with biological activity. Although these SMs do not completely determine the flavor of the fruits, they are of great influence. Tables 6, 7 show the concentrations of cucurbitacins and flavonoids per group of genotypes. The sweet fruits showed a sum of $12.59 \mathrm{mg} \mathrm{g}^{-1}$, neutral showed $12.00 \mathrm{mg} \mathrm{g}^{-1}$, and bitter showed $24.78 \mathrm{mg} \mathrm{g}^{-1}$.

\section{DISCUSSION}

The type of metabolite present in chayote gives each fruit its characteristic flavor. For example, in a previous study (Tallamy and Krischik, 1989), it was mentioned that the qualitative composition of cucurbitacins among species of Cucurbita spp. was mutually exclusive. That is to say, the species produces cucurbitacins B and D, or cucurbitacins E and I, with additional qualitative variation in the production of bitter glycosides, where $\mathrm{B}$ and $\mathrm{D}$ are synthesized mainly as aglicones, while $\mathrm{E}$ and I are regularly produced in considerable amounts of glucosides. With Sechium, there was no synthesis excluding cucurbitacins per

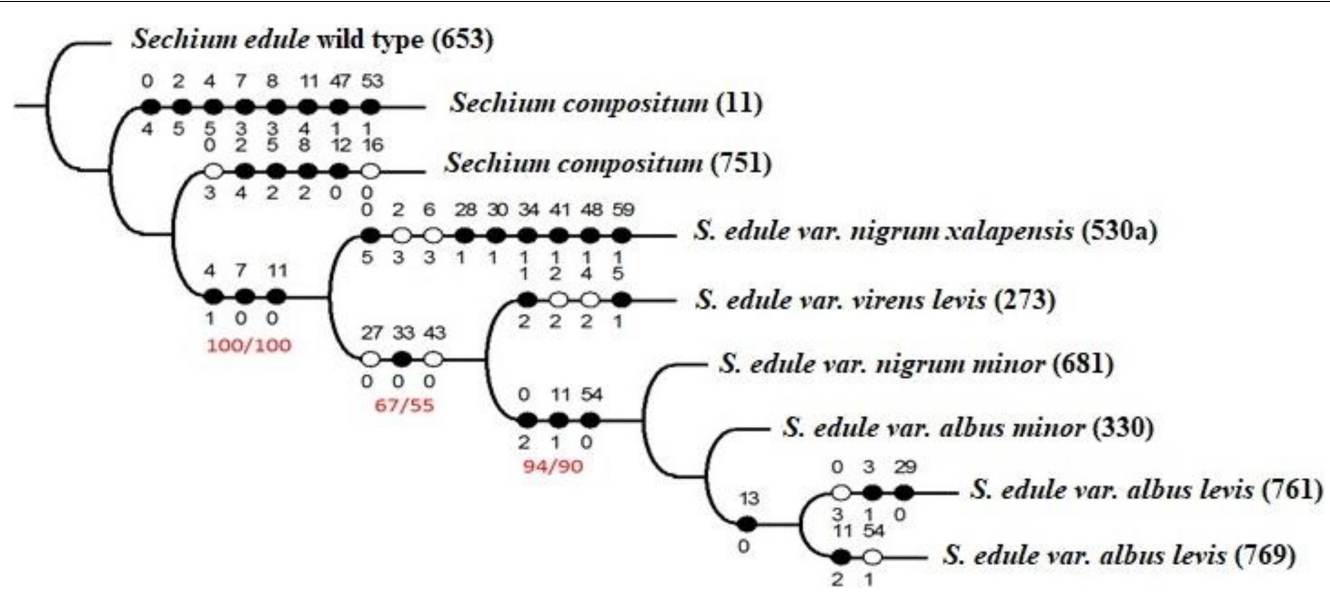

FIGURE 2 | Cladogram with nine genotypes (accessions) of Sechium spp., with phytochemical profile values (cucurbitacins and flavonoids), as well as AFLP polymorphic bands in combination with ECORI ACC and Mse1 CAT. The white circle corresponds to the new traits, the black circle to the ancestral traits, and the values in the higher part of the circle reveal the trait and lower value of it, in its state. $L=87, C i=72, R i=38$, and values $100 / 100,67 / 55$, and $94 / 90$ for the bootstrap/jack knife tests, respectively. 
TABLE 5 | Plesiomorphic and apomorphic traits, from the analysis of 12 biochemical variables and 48 polymorphic bands of AFLPs, from Sechium spp. (Phytochemical trait 0-11; AFLP bands: 12-59).

\begin{tabular}{lcc}
\hline Genotype/accession & Trait/status of trait per clade & Internal clade \\
\hline Sechium edule wild type 653 & $0 / 4,2 / 5,4 / 5,7 / 3,8 / 3,11 / 4$, & $4 / 1,7 / 0,11 / 0$, \\
& $47 / 1,53 / 1$ & \\
Sechium compositum 11 & $0 / 2,2 / 4,5 / 2,8 / 2,12 / 0,16 / 0$ & \\
Sechium compositum 751 & $0 / 5,2 / 3,6 / 3,28 / 1,30 / 1,31 / 1$, & \\
& $41 / 1,48 / 1,59 / 1$ & $27 / 0,33 / 0,43 / 0$ \\
S. edule var. nigrum xalapensis & $1 / 2,2 / 2,4 / 5,5 / 1$ & $0 / 2,11 / 1,54 / 0$ \\
530a & $0 / 2,11 / 1,54 / 0$ & $13 / 0$ \\
S. edule var. virens levis 273 & & \\
S. edule var. nigrum minor 681 & $0 / 3,3 / 1,29 / 0$ & \\
S. edule var. albus minor 330 & $11 / 2,54 / 1$ & \\
S. edule var. albus levis 761 & & \\
S. edule var. albus levis 769 & &
\end{tabular}

TABLE 6 | Mean concentration of cucurbitacins related to the flavor of the fruit from Sechium spp. Values obtained from $n=27 \pm$ standard error.

\begin{tabular}{|c|c|c|c|c|c|}
\hline Group & CuD & Cul & $\mathrm{CbB}$ & CuE & $\Sigma$ SMs \\
\hline Sweet & $6.22 \pm 3.4$ & $3.24 \pm 0.69$ & $1.08 \pm 0.32$ & $0.58 \pm 0.58$ & 11.12 \\
\hline Neutral & $5.15 \pm 4.14$ & $5.16 \pm 0.57$ & $0.54 \pm 0.14$ & 0.00 & 10.85 \\
\hline Bitter & $4.13 \pm 2.18$ & $8.43 \pm 4.55$ & $2.17 \pm 1.21$ & 0.00 & 14.73 \\
\hline
\end{tabular}

genotype, because $\mathrm{D}$, I, and B appeared in all genotypes, and only $\mathrm{E}$ was identified in a sweet accession. This suggests that there is no exclusion of synthesis, but there are differences in terms of concentration.

A previous study (Ríos et al., 2012) mentioned cucurbitacin I (also called JSI-124) as a selective inhibitor of phosphorylate tyrosine JAK3/STAT3, and may be considered a potential anticancer agent in addition to cucurbitacins $\mathrm{E}$ and $\mathrm{B}$. It has been previously reported (Takahashi et al., 2009) that cucurbitacin D acts as an inducer of apoptosis in hepatic carcinoma. The evaluated extracts revealed the presence of compounds with possible therapeutic interest, such as cucurbitacins and flavonoids, as reported in different fruits of chayote of separate genetic lineage (Cadena-Iñiguez et al., 2013; Aguiñiga-Sánchez et al., 2017; Salazar-Aguilar et al., 2017), whose antineoplastic and antiproliferative activity has also been previously determined (Petronelli et al., 2009; Bishayeen et al., 2011; Soto-Hernández et al., 2015).

Plants are the excellent source of SM and/or antioxidants. There are compounds that are not of direct use for the survival of plants but help organisms to function more optimally in their environment (Piasecka et al., 2015), such as SMs (O'Connor,
2015) which include phenolics and flavonoids, hydroxybenzoic acids (Sarker and Oba, 2019a), hydroxycinnamic acids (Sarker et al., 2020c), flavanols (Sarker et al., 2020b; Sarker and Oba, 2020b), flavones (Sarker and Oba, 2020e), flavanones (Sarker and Oba, 2020f), tocopherols (Sarker and Oba, 2020d), betalains (Sarker and Oba, 2021), ascorbic acid (Sarker and Oba, 2020c), carotenoids (Sarker and Oba, 2020a), betacyanin (Sarker et al., 2020a), betaxanthin (Sarker and Oba, 2019b), chlorophyll a and b (Sarker et al., 2018a; Sarker and Oba, 2019c), and beta-carotene (Sarker et al., 2018b).

Their production is frequently associated with conditions of biotic and abiotic stress, with the most harmful being the high incidence of light and nutritional deficiencies (Schlaepfer and Mendoza-Espinoza, 2010), thus leading to their carbon-based biosynthesis (phenolic). According to the carbon nutrient balance (CNB) hypothesis, in the case of nitrogen limitation, the SMs lean toward carbon-rich metabolites (phenols and terpenes), and when there is carbon limitation, there is an increase in nitrogen-rich metabolites (alkaloids) (Hamilton et al., 2001; Palumbo et al., 2007).

The literature has shown that any stresses like drought and salinity create reactive oxygen species (ROS) (Sarker and Oba, 2018b), osmotic stress (Sarker and Oba, 2020g), decrease in photosynthetic activities (Sarker and Oba, 2018d), nutrient imbalance (Sarker et al., 2018), and ultimately cause oxidative damage in plant cells (Sarker and Oba, 2018c), that affects the growth and productivity of crops (Sarker and Oba, 2019d). However, to detoxify ROS and cope with stresses, plant evolved mechanisms to augment the concentration of these SMs and/or antioxidants (Sarker and Oba, 2018a).

In this regard, it should be noted that the domesticated and semi-domesticated genotypes of Sechium provide nutrients (preferably nitrogenous) in their life history, suggesting an influence on the lower concentration of flavonoids and triterpenes, and, contrary to bitter types, these genotypes may exhibit deficiencies in their wild states, thereby increasing the amount of triterpenes and flavonoids. Hence, stress augments SMs content that can be used in food, cosmetic and pharmaceutical industry.

The probable movement that gave rise to the chayote varieties of Sechium spp. highlights the environmental variables and the manipulation that work together to select edible forms. This would promote scenarios for adaptation, where the plasticity of the genus would have mainly allowed morphological and biochemical variations. The semi-domesticated genotypes of yellow fruit express metabolites that can provide carotenoids with greater protection from solar radiation. These fruits are relatively small, which may decrease the area of incidence of

TABLE 7 | Mean concentration of flavonoids related to the flavor of fruit from Sechium spp. Values obtained from $n=27 \pm$ standard error.

\begin{tabular}{|c|c|c|c|c|c|c|c|c|}
\hline Group & $\mathbf{R u}$ & Fz & My & Qu & $\mathrm{Na}$ & $\mathbf{F t}$ & Ga & $\Sigma$ SMs \\
\hline Sweet & $0.21 \pm 0.04$ & 0.00 & $0.67 \pm 0.07$ & 0.00 & $0.05 \pm 0.05$ & $0.08 \pm 0.02$ & $0.46 \pm 0.02$ & 1.47 \\
\hline Neutral & $0.15 \pm 0.05$ & $0.03 \pm 0.03$ & $0.71 \pm 0.24$ & 0.0037 & 0.00 & $0.11 \pm 0.03$ & $0.15 \pm 0.15$ & 1.15 \\
\hline Bitter & $0.83 \pm 0.21$ & $0.36 \pm 0.04$ & $0.92 \pm 0.37$ & $0.11 \pm 0.05$ & $0.72 \pm 0.46$ & $1.23 \pm 0.62$ & $6.21 \pm 3.42$ & 10.05 \\
\hline
\end{tabular}

$R u=$ rutin; Fz = florizidin; $M i=$ myricetin; $Q u=$ quercetin; Na = naringenin; Ft = floretin; $\mathrm{Ga}=$ galangin . 
radiation and lower the amount of water compared to the domesticated materials, thereby modifying the expression of metabolites that provide protection against predators, such as cucurbitacins (Piasecka et al., 2015).

This is relevant because flavonols show higher protection activity at the level of the cell membrane (López-Revuelta et al., 2006), acting as antiradicals, antichelants, lipid antioxidants, antimutagens, and having an antiproliferative effect, thereby inhibiting carcinogenesis (Martínez-Flórez et al., 2002).

Considering the change in diversity and type of SMs found in the genotypes of Sechium spp., it is possible that certain current changes, such as flavor, color, and size, are a direct product of adjustments in the biosynthesis of the mevalonic acid pathway. For example, when photoprotective pigments are required in the fruit, the amount of triterpenes decreases, and with it, the bitter flavor of the fruits, in addition to gradually showing changes in color from dark green to light green with yellow colors of the epidermis. In addition to this, a previous report (Cadena-Iñiguez et al., 2011) described how the ascorbic acid in yellow fruits was attributed to the need for photoprotection, which coincides with the fact that the fruits of edible genotypes of Sechium spp. present stomas found in the epidermis (Cadena-Iñiguez et al., 2006). These results assist in explaining the causality of certain morphological variables in Sechium spp., in addition to evidencing relevant phytochemical variables that may guide the selection of sweet, neutral, and bitter genotypes, to design grossbreeding.

The cucurbitacins and flavonoids found have demonstrated anti-proliferative, antioxidant, and chelating activity, DNA fragmentation, and apoptosis induction (previously mentioned). However, the evaluated genotypes show contrasts in terms of content and diversity. Some flavonoid and terpenoid derivatives, such as cucurbitacins in one genotype, are at risk of generating intrinsic toxicity (Marinoff et al., 2009), thereby causing longterm intoxication. Therefore, it is important to understand the main phytochemicals and obtain new varieties of Sechium showing therapeutic and nutraceutical activity values that are easier to manage for human health and nutrition.

An important fact about the search and identification of natural compounds from species and genotypes little used and that are part of agrobiodiversity, is that when they are not used the trend is their loss in the medium term (Food and Agriculture Organization [FAO], 2019), therefore, this work highlights the opportunity to have alternative sources of inputs for health, pharmacology, and food industry.

\section{CONCLUSION}

The cladistic analysis can identify and contrast the diversity of cucurbitacins and flavonoids, suggesting that they are

\section{REFERENCES}

Aguiñiga-Sánchez, I., Cadena-Îñiguez, J., Santiago-Osorio, E., Gómez-García, G., Mendoza-Núñez, V. M., Rosado-Pérez, J., et al. (2017). Chemical analyses and in vitro and in vivo toxicity of fruit methanol extract of Sechium edule var. related to the polymorphic genetic bands in nine genotypes of Sechium, where the bitter flavors (wild) showed a greater number of ancestral traits, which makes them genetically and phytochemically more complex. Flavonoids were present in higher concentrations in genotypes as compared to those of cucurbitacins. However, both groups of metabolites are associated with therapeutic and nutraceutical activity, highlighting genotypes as an important source of biomass and metabolites of interest.

\section{DATA AVAILABILITY STATEMENT}

The raw data supporting the conclusions of this article will be made available by the authors, without undue reservation.

\section{AUTHOR CONTRIBUTIONS}

JC-I and RS-H: conceptualization. MI-L, RS-H, and KW: investigation. FM-F and MC-C: software, formal analysis, and data curation. MI-L, JC-I, and RS-H: writing - original draft.

\section{FUNDING}

This research was supported in part by Plant Transgenic Design Initiative (PTraD) at Tsukuba Plant Innovation Research Center, University of Tsukuba, Japan.

\section{ACKNOWLEDGMENTS}

The authors thank the Interdisciplinary Research Group of Sechium edule in Mexico (GISeM) for providing the biological material and the laboratory staff of the Phytochemical Lab of Colegio de Postgraduados for their technical support. The research was conducted in part as an extension of SATREPS (Diversity Assessment and Development of Sustainable Use of Mexican Genetic Resources 2012-2018) and DIGEM. Also, the research was supported in part by the Plant Transgenic Design Initiative (P-TraD) at Ksukuba Plant Innovation Research Center, University of Tsukuba, Japan.

\section{SUPPLEMENTARY MATERIAL}

The Supplementary Material for this article can be found online at: https://www.frontiersin.org/articles/10.3389/fpls.2021. 772389/full\#supplementary-material

nigrum spinosum. Pharm. Biol. 55, 1638-1645. doi: 10.1080/13880209.2017. 1316746

Aguiñiga-Sánchez, I., Soto-Hernández, R. M., Cadena-Iñiguez, J., Ruiz-Posadas, L., Cadena-Zamudio, J. D., González-Ugarte, A. K., et al. (2015). Fruit extract from a Sechium edule hybrid induce apoptosis in leukaemic cell lines but 
not in normal cells. Nutr. Cancer 67, 250-257. doi: 10.1080/01635581.2015.98 9370

Bishayeen, A., Ahmed, S., Brankov, N., and Perloff, M. (2011). Triterpenoids as potential agents for the chemoprevention and therapy of breast cancer. Front. Biosci. 16:980. doi: 10.2741/3730

Bourgaud, F., Gravot, A., Milesi, S., and Gontier, E. (2001). Production of plant secondary metabolites: a historical perspective. Plant Sci. 161, 839-851. doi: 10.1016/S0168-9452(01)00490-3

Cadena-Iñiguez, J., Arévalo-Galarza, M. L., Ruiz-Posadas, L. M., Aguirre-Medina, J. F., Soto-Hernández, R. M., Luna-Cavazos, M., et al. (2006). Quality evaluation and influence of 1-MCP on Sechium edule fruit during postharvest. Postharvest Biol. Technol. 40, 170-176. doi: 10.1016/j.postharvbio.2005.12.013

Cadena-Iñiguez, J., Soto-Hernández, R. M., Arévalo-Galarza, M. L., AvendañoArrazate, C. H., Aguirre-Medina, J. F., and Ruíz-Posadas, L. M. (2011). Caracterización bioquímica de variedades domesticadas de chayote Sechium edule (Jacq.) Sw. comparadas con parientes silvestres. Rev. Chapingo. Ser. Hortic. 17, 45-55.

Cadena-Iñiguez, J., Soto-Hernández, R. M., Torres, A., Aguiñiga-Sánchez, I., RuízPosadas, L. M., Rivera-Martínez, A. R., et al. (2013). The antiproliferative effect of chayote varieties (Sechium edule (Jacq.) Sw.) on tumour cell lines. J. Med. Plants Res. 7, 455-460. doi: 10.5897/JMPR12.866

Convention on Biological Diversity (2020). Recommendation Adopted by the Open-Ended Working Group on the Post 2020 Global Biodiversity Framework. United Nations. Available online at: https://www.cbd.int/doc/ recommendations/wg2020-02/wg2020-02-rec-01-en.pdf

Croteau, R., Kutchan, T. M., and Lewis, N. G. (2000). "Natural products (secondary metabolites)," in Biochemistry and Molecular Biology of Plants, eds B. Buchanan, W. Grussem, and R. Jones (Rockville, MD: American Society of Plant Physiologists), 1250-1318.

Deschner, E. E., Ruperto, J., Wong, W., and Newmark, H. L. (1993). The effect of dietary quercetin and rutin on AOM-induced acute colonic epithelial abnormalities in mice fed a high-fat diet. Nutr. Cancer 20, 199-204. doi: 10. $1080 / 01635589309514287$

Felsenstein, J. (1985). Confidence limits on phylogenies: an approach using thebootstrap. Evolution 39, 783-791. doi: 10.1111/j.1558-5646.1985.tb00420.x

Food and Agriculture Organization [FAO] (2019). "The state of the world's biodiversity for food and agriculture," in FAO Commission on Genetic Resources for Food and Agriculture Assessments, eds J. Bélanger and D. Pilling (Rome: FAO), 572.

Hamilton, J. G., Zangerl, A. R., DeLucia, E. H., and Berenbaum, M. R. (2001). The carbon-nutrient balance hypothesis: it rise and fall. Ecol. Lett. 4, 86-95. doi: 10.1046/j.1461-0248.2001.00192.x

Jacobo-Herrera, N. J., Jacobo-Herrera, F. E., Zentella-Dehesa, A., AndradeCetto, A., Heinrich, M., and Pérez-Plasencia, C. (2016). Medicinal plants used in Mexican traditional medicine for the treatment of colorectal cancer. J. ethnopharmacol. 179, 391-402. doi: 10.1016/j.jep.2015.12.042

Lanyon, S. M. (1985). Detecting internal inconsistencies in distances data. Syst. Zool. 34, 397-403. doi: 10.2307/2413204

Leon-Lobos, P., Way, M., Aranda, D. P., and Lima-Junior, M. (2012). The role of ex situ seed banks in the conservation of plant diversity and in ecological restoration in Latin America. Planta Ecol. Divers. 5, 245-258.

Lira, R., Castrejón, J., Zamudio, S., and Rojas-Zenteno, C. (1999). Propuesta de ubicación taxonómica para los chayotes silvestres (Sechium edule, Cucurbitaceae) de México. Acta Bot. Mex. 49, 47-61.

López-Revuelta, A., Sánchez-Gallego, J. I., Hernández-Hernández, A., SánchezYagüe, J., and Llanillo, M. (2006). Membrane cholesterol contents influence the protective effects of quercetin and rutin in erythrocytes damaged by oxidative stress. Chem. Biol. Interact. 161, 79-91. doi: 10.1016/j.cbi.2006.03.004

Manach, C., Regerat, F., Texier, O., Agullo, G., Demigne, C., and Remesy, C. (1996). Bioavailability, metabolism and physiological impact of 4-oxo-flavonoids. Nutr. Res. 16, 517-544. doi: 10.1016/0271-5317(96)00032-2

Marinoff, M. A., Martínez, J. L., and Urbina, M. A. (2009). Precauciones en el empleo de plantas medicinales. Bol. Latinoam. Caribe Plantas Med. Aromát. 8, 184-187.

Martínez-Flórez, S., González-Gallego, J., Culebras, J. M., and Tuñón, M. (2002). Los flavonoides: propiedades y acciones antioxidantes. Nutr. Hosp. 17, 271-278.

Molina-Mendoza, J. L., Galván-Villanueva, R., Patiño-siciliano, A., and FernándezNava, R. (2012). Plantas medicinales y listado florístico preliminar del municipio de Huasca de Ocampo, Hidalgo, México. Polibotánica 34, 259-291.

O'Connor, S. E. (2015). Engineering of secondary metabolism. Annu. Rev. Genet. 49, 71-94. doi: 10.1146/annurev-genet-120213-092053

Palma-Tenango, M., San Miguel-Chávez, R., and Soto-Hernández, R. M. (2017). "Aromatic and medicinal plants in mexico," in Aromatic and Medicinal Plants Back to Nature, ed. H. A. El-Shemy (London: InTechOpen).

Palumbo, M. J., Putz, F. E., and Talcott, S. T. (2007). Nitrogen and gender effects on the secondary metabolism of yaupon, a caffeine-containing North American holly. Oecologia . 151, 1-9. doi: 10.1007/s00442-006-0574-1

Petronelli, A., Pannitteri, G., and Testa, U. (2009). Triterpenoids as new promising anticancer drugs. Anticancer Drugs 20, 880-892. doi: 10.1097/CAD. 0b013e328330fd90

Piasecka, A., Jedrzejczak-Rey, N., and Bednarek, P. (2015). Secondary metabolites in plant innate immunity: conserved function of divergent chemicals. New Phytol. 206, 948-964. doi: 10.1111/nph.13325

Ríos, L. J., Andújar, I., Escandell, M. J., Giner, M. R., and Recio, C. M. (2012). Cucurbitacins as inducers of cell death and a rich source of potential anticancer compounds. Curr. Pharm. Des. 18, 1663-1676. doi: 10.2174/ 138161212799958549

Roskov, Y., Abucay, L., Orrell, T., Nicolson, D., Kunze, T., Flann, C., et al. (eds) (2015). Species 2000 \& ITIS Catalogue of Life, 28th September 2015. Leiden: Species 2000.

Salazar-Aguilar, S., Ruiz-Posadas, L. D. M., Cadena-Iñiguez, J., Soto-Hernández, M., Santiago-Osorio, E., Aguiñiga-Sánchez, I., et al. (2017). Sechium edule (Jacq.) swartz, a new cultivar with antiproliferative potential in a human cervical cancer HeLa cell line. Nutrients 9:798. doi: 10.3390/nu908 0798

Sarker, U., and Oba, S. (2018a). Augmentation of leaf color parameters, pigments, vitamins, phenolic acids, flavonoids and antioxidant activity in selected Amaranthus tricolor under salinity stress. Sci. Rep. 8:12349. doi: 10.1038/ s41598-018-30897-6

Sarker, U., and Oba, S. (2018b). Catalase, superoxide dismutase and ascorbateglutathione cycle enzymes confer drought tolerance of Amaranthus tricolor. Sci. Rep. 8:16496. doi: 10.1038/s41598-018-34944-0

Sarker, U., and Oba, S. (2018d). Response of nutrients, minerals, antioxidant leaf pigments, vitamins, polyphenol, flavonoid and antioxidant activity in selected vegetable amaranth under four soil water content. Food Chem. 252, 72-83. doi: 10.1016/j.foodchem.2018.01.097

Sarker, U., and Oba, S. (2018c). Drought stress effects on growth, ROS markers, compatible solutes, phenolics, flavonoids, and antioxidant activity in Amaranthus tricolor. Appl. Biochem. Biotechnol. 186, 999-1016. doi: 10.1007/ s12010-018-2784-5

Sarker, U., and Oba, S. (2019b). Nutraceuticals, antioxidant pigments, and phytochemicals in the leaves of Amaranthus spinosus and Amaranthus viridis weedy species. Sci. Rep. 9:20413. doi: 10.1038/s41598-019-50977-5

Sarker, U., and Oba, S. (2019c). Protein, dietary fiber, minerals, antioxidant pigments and phytochemicals, and antioxidant activity in selected red morph Amaranthus leafy vegetable. PLoS One 14:e0222517. doi: 10.1371/journal.pone. 0222517

Sarker, U., and Oba, S. (2019d). Salinity stress enhances color parameters, bioactive leaf pigments, vitamins, polyphenols, flavonoids and antioxidant activity in selected Amaranthus leafy vegetables. J. Sci. Food Agric. 99, 2275-2284. doi: $10.1002 /$ jsfa. 9423

Sarker, U., and Oba, S. (2019a). Antioxidant constituents of three selected red and green color Amaranthus leafy vegetable. Sci. Rep. 9:18233. doi: 10.1038/s41598019-52033-8

Sarker, U., and Oba, S. (2020b). Nutraceuticals, phytochemicals, and radical quenching ability of selected drought-tolerant advance lines of vegetable amaranth. BMC Plant Biol. 20:564. doi: 10.1186/s12870-02002780-y

Sarker, U., and Oba, S. (2020e). Phenolic profiles and antioxidant activities in selected drought-tolerant leafy vegetable amaranth. Sci. Rep. 10:18287. doi: 10.1038/s41598-020-71727-y

Sarker, U., and Oba, S. (2020f). Polyphenol and flavonoid profiles and radical scavenging activity in leafy vegetable Amaranthus gangeticus. BMC Plant Biol. 20:499. doi: 10.1186/s12870-020-02700-0 
Sarker, U., and Oba, S. (2020d). Nutritional and bioactive constituents and scavenging capacity of radicals in Amaranthus hypochondriacus. Sci. Rep. 10:19962. doi: 10.1038/s41598-020-71714-3

Sarker, U., and Oba, S. (2020c). Nutrients, minerals, pigments, phytochemicals, and radical scavenging activity in Amaranthus blitum leafy vegetables. Sci. Rep. 10:3868. doi: 10.1038/s41598-020-59848-w

Sarker, U., and Oba, S. (2020a). Leaf pigmentation, its profiles and radical scavenging activity in selected Amaranthus tricolor leafy vegetables. Sci. Rep. 10:18617. doi: 10.1038/s41598-020-66376-0

Sarker, U., and Oba, S. (2020g). The response of salinity stress-induced A. tricolor to Growth, anatomy, physiology, non-enzymatic and enzymatic antioxidants. Front. Plant Sci. 11:559876. doi: 10.3389/fpls.2020.559876

Sarker, U., and Oba, S. (2021). Color attributes, betacyanin, and carotenoid profiles, bioactive components, and radical quenching capacity in selected Amaranthus gangeticus leafy vegetables. Sci. Rep. 11:11559. doi: 10.1038/s41598-021-9 1157-8

Sarker, U., Oba, S., and Daramy, M. A. (2020c). Nutrients, minerals, antioxidant pigments and phytochemicals, and antioxidant capacity of the leaves of stem amaranth. Sci. Rep. 10:3892. doi: 10.1038/s41598-020-60252-7

Sarker, U., Hossain, M. N., Iqbal, M. A., and Oba, S. (2020b). Bioactive components and radical scavenging activity in selected advance lines of salttolerant vegetable amaranth. Front. Nutr. 7:587257. doi: 10.3389/fnut.2020.58 7257

Sarker, U., Hossain, M. M., and Oba, S. (2020a). Nutritional and antioxidant components and antioxidant capacity in green morph Amaranthus leafy vegetable. Sci. Rep. 10:1336. doi: 10.1038/s41598-020-57687-3

Sarker, U., Islam, M. T., and Oba, S. (2018). Salinity stress accelerates nutrients, dietary fiber, minerals, phytochemicals and antioxidant activity in Amaranthus tricolor leaves. PLoS One 13:e0206388. doi: 10.1371/journal.pone.020 6388

Sarker, U., Islam, T., Rabbani, G., and Oba, S. (2018a). Antioxidant leaf pigments and variability in vegetable amaranth. Genetika 50, 209-220. doi: 10.2298/ GENSR1801209S

Sarker, U., Islam, T., Rabbani, G., and Oba, S. (2018b). Variability in total antioxidant capacity, antioxidant leaf pigments and foliage yield of vegetable amaranth. J. Integr. Agric. 17, 1145-1153. doi: 10.1016/S2095-3119(17)61778-7

Schlaepfer, L., and Mendoza-Espinoza, J. A. (2010). Las plantas medicinales en la lucha contra el cáncer, relevancia para México. Rev. Mex. Cienc. Farm. 41, $18-27$.

Shagai-maroof, M. A., Soliman, K. M., Jorgensen, R. A., and Allard, R. W. (1984). Ribosomal spacer length polymorphisms in barley: mendelian inheritance, chromosomal location and population dynamics. Proc. Natl. Acad. Sci. U.S.A. 81, 8014-8019. doi: 10.1073/pnas.81.24.8014
SIAP (2019). Servicio de Información Agroalimentaria y Pesquera. Estadísticas. Available online at: http://infosiap.siap.gob.mx/gobmx/datosAbiertos.php (accessed August 27, 2020).

Soto-Hernández, R. M., Cadena-Iñiguez, J., Arevalo-Galarza, L. C., SantiagoOsorio, E., Aguiñiga- Sánchez, I., and Ruíz-Posada, L. M. (2015). "Lead compound from Cucurbitaceae for the treatment of cancer," in Chapter 12 Phytochemical Isolation, Characterization and Role in Human Health, Vol. 12, eds A. Venket Rao and L. G. Rao (London: IntechOpen), 289-303. doi: 10.5772/ 60048

Takahashi, N., Yoshida, Y., Sugiura, T., Matsuno, K., Fujino, A., and Yamashita, A. (2009). Cucurbitacin D isolated from Trichosanthes kirilowii induces apoptosis in human hepatocellular carcinoma cells in vitro. Int. immunopharmacol. 9, 508-513. doi: 10.1016/j.intimp.2009.01.006

Tallamy, D. W., and Krischik, V. A. (1989). Variation and function of cucurbitacins in Cucurbita: an examination of current hypotheses. Am. Nat. 133, 766-786.

Vega, ÁE., Velasco-Lezama, R., and Jiménez-Estrada, M. (2006). Las plantas como fuente de compuestos antineoplásicos. Rev. Bioquím. 31, 97-111.

Villaseñor, J. L. (2016). Checklist of native vascular plants of México. Rev. Mex. Biodivers. 87, 559-902. doi: 10.1016/j.rmb.2016.06.017

Vos, P., Hogers, R., Bleeker, M., Reijans, M., Lee, T. V. D., Hornes, M., et al. (1995). AFLP: a new technique for DNA fingerprinting. Nucleic Acids Res. 23, 4407-4414.

WinClada v.1.00.08 (2020). WinClada - FREE Download WinClada 1.00.08 Components \& Libraries Development. Available online at: https://www. scienceopen.com/document?vid=3c4c21f5- $\mathrm{f} 2 \mathrm{fc}-49 \mathrm{~b} 1-\mathrm{a} 18 \mathrm{e}-4 \mathrm{fba} 2 \mathrm{f} 1337 \mathrm{~d} 7$

Conflict of Interest: The authors declare that the research was conducted in the absence of any commercial or financial relationships that could be construed as a potential conflict of interest.

Publisher's Note: All claims expressed in this article are solely those of the authors and do not necessarily represent those of their affiliated organizations, or those of the publisher, the editors and the reviewers. Any product that may be evaluated in this article, or claim that may be made by its manufacturer, is not guaranteed or endorsed by the publisher.

Copyright (c) 2021 Iñiguez-Luna, Cadena-Iñiguez, Soto-Hernández, Morales-Flores, Cortes-Cruz and Watanabe. This is an open-access article distributed under the terms of the Creative Commons Attribution License (CC BY). The use, distribution or reproduction in other forums is permitted, provided the original author(s) and the copyright owner(s) are credited and that the original publication in this journal is cited, in accordance with accepted academic practice. No use, distribution or reproduction is permitted which does not comply with these terms. 